\title{
PANDANGAN MUHAMMAD RIZIEQ SHIHAB TENTANG PANCASILA
}

\author{
M. Iqbal Maula \\ Magister Studi Agama-Agama UIN SGD Bandung, Indonesia \\ i.mevla.88@gmail.com
}

\begin{abstract}
This paper seeks to describe the perspective of al-Habib Muhammad Rizieq bin Hussein Shihab on Pancasila. At the beginning of the paper, the author will be explained in advance how the concept of the state according to the Sharia, that is divided into two main ideas, literalism-textual and substantialism-contextual. Furthermore, it will be more elaborated on the debate in filling the ideology of the state of Islam and nationalist groups in the period of national movement. Then, the author will describe the interpretation of al-Habib Muhammad Rizieq bin Husein Shihab in the interpreting of Pancasila with the historical approach. Finally, the author critically examines this view which shows that the misinterpretation of al-Habib Muhammad Rizieq bin Hussein Shihab in understanding Pancasila.
\end{abstract}

Keywords: Pancasila; Habib Rizieq; Syariah; Islam in Indonesia.

\begin{abstract}
Abstrak
Tulisan ini berusaha mendeskripsikan pandangan al-Habib Muhammad Rizieq bin Husein Shihab tentang Pancasila. Pada awal tulisan akan dijelaskan terlebih dahulu bagaimana konsep negara menurut syariah yang terbagi dalam dua paham utama yaitu literalis-tekstualis dan substansial-kontekstual. Selanjutnya akan dielaborasi lebih lanjut tentang perdebatan dalam mengisi ideologi negara dari golongan Islam dan nasionalis di masa pergerakan nasional. Kemudian penulis akan memaparkan bagaimana interpretasi al-Habib Muhammad Rizieq bin Husein Shihab dalam memaknai Pancasila dengan pendekatan historis. Akhirnya, penulis menelaah secara kritis pandangan tersebut yang menunjukkan bahwa adanya misinterpretasi yang dilakukan al-Habib Muhammad Rizieq bin Husein Shihab dalam memahami Pancasila.
\end{abstract}

Kata kunci: Pancasila; Habib Rizieq; Syariah; Islam di Indonesia.

\section{PENDAHULUAN}

Senin, 30 Januari 2017, Muhammad Rizieq Bin Husein Shihab alias Habib Rizieq resmi ditetapkan sebagai tersangka karena melanggar Pasal 154 a KUHP tentang penodaan terhadap lambang negara dan Pasal 320 KUHP tentang pencemaran terhadap orang yang sudah meninggal. Pelaporan tersebut dilakukan oleh putri Soekarno, Sukmawati
Soekarnoputri setelah melihat video yang diunggah pada tahun 2014 dimana Habib Rizieq, dalam video itu dinilai telah menghina Soekarno dengan mengatakan bahwa "Pancasila Soekarno, Ketuhanan ada di pantat sedangkan Pancasila Piagam Jakarta Ketuhanan ada di kepala". ${ }^{1}$ Peristiwa

\footnotetext{
${ }^{1}$ Emma Mardiana, "Ini Kronologi Kasus Dugaan Penodaan Pancasila Oleh Habib Rizieq," 2017, https://news.detik.com/berita/d-3409531/ini-
} 
ini sontak memunculkan berbagai reaksi, khususnya organisasi masyarakat FPI (Front Pembela Islam) yang dipimpinnya sempat bentrok dengan organisasi masyarakat GMBI (Gerakan Masyarakat Bawah Indonesia) di depan POLDA Jabar ketika dirinya diperiksa sebagai saksi. ${ }^{2}$ Konflik yang terjadi saat itu tidak lain adalah adanya interpretasi yang berbeda yang dipahami oleh Habib dalam memahami Pancasila sebagai ideologi negara.

Al-Habib Muhammad Rizieq bin Husein Shihab atau yang biasa dikenal dengan Habib Rizieq menilai bahwa Pancasila yang berlaku saat ini adalah inkostitusional karena menurutnya Presiden Indonesia tidak pernah mencabut Dekrit Presiden Soekarno tahun 1959 yang menyatakan UndangUndang Dasar haruslah kembali ke UUD 1945. Dengan demikian maka saat ini lazimya Piagam Jakarta yang berlaku dengan menekankan bahwa “Ketuhanan dengan kewajiban menjalankan syariat Islam bagi pemeluk-pemeluknya" bukan Ketuhanan Yang Maha Esa. Penilaian tersebut disampaikan olehnya melalui ceramah-ceramah dan buku yang telah ditulisnya berjudul "Wawasan Kebangsaan Menuju NKRI Bersyariah" dan Tesisnya di Universiti Malaya di Malaysia yaitu "Pengaruh Pancasila terhadap Penerapan Syariat Islam di Indonesia."

Tulisan ini mendiskusikan Pancasila menurut al-Habib Muhammad Rizieq bin Husein Shihab. ${ }^{3}$

kronologi-kasus-dugaan-penodaan-pancasila-olehhabib-rizieq. diakses 1 Januari 2018.

${ }^{2}$ https://nasional.tempo.co/read/835425/rizieqdiperiksa-polisi-fpi-bentrok-dengan-ormas-dibandung 12 Januari 2017 (18/3/2020).

3 Selanjutnya penulis akan menggunakan nama Habib Rizieq yang lazimnya dikenal di masyarakat Indonesia.
Di awal tulisan penulis akan memaparkan dua pandangan umum tentang hubungan antara Islam dan negara yang bersifat literal-tekstualis dan substansial-konstektual. Pada bagian selanjutnya akan dibahas tentang bagaimana perdebatan antara golongan Islam dan Nasionalis dalam mengisi ideologi negara Indonesia. Kemudian di bagian akhir akan menjelaskan tentang perspektif alHabib Muhammad Rizieq bin Husain Shihab tentang Pancasila.

Dalam penelitian ini penulis menggunakan pendekatan kualitatif dengan sumber data kepustakaan (library research) dan data-data lainnya yang menunjang. Sumber data primer dalam tulisan ini adalah karya-karya tulis al-Habib Muhammad Rizieq bin Husein Shihab sendiri sedangkan data sekunder yang menjadi penunjangnya berupa laporan-laporan, ceramah keagamaan, artikel-artikel dan dokumen-dokumen lainnya yang relevan dengan objek pembahasan. Analisis data dalam penelitian ini adalah analisis isi (content analysis) yang berupaya untuk memahami, mendefinisikan, membandingkan, menguraikan serta menyelidiki konsep Pancasila menurut al-Habib Muhammad Rizieq bin Husein Shihab.

\section{HASIL DAN PEMBAHASAN Hubungan Islam dan Negara}

Menurut Fazlur Rahman, Islam dimaknai sebagai "way of life" memberikan panduan moral yang benar bagi tindakan manusia ${ }^{4}$ dan mencakup hidup yang total (käffah) yang dinyatakan dalam syariah. Dengan kata lain Islam merupakan sebuah totalitas kesempurnaan yang

${ }^{4}$ Fazlur Rahman, Islam (Chicago: Winston, 1966). 241. 
memberikan solusi pada seluruh aspek kehidupan manusia. Pandangan ini ditegaskan dalam al-Qur'an dalam surat al-Nahl ayat 89: ..."dan Kami turunkan kepadamu Al-kitab (Al-Quran) untuk menjelaskan segala sesuatu dan petunjuk serta rahmat dan kabar gembira bagi orang-orang yang berserah diri."

Pandangan totalitas seperti ini mempunyai konsekuensi dalam memahami Islam, baik secara literaltekstual dan eksklusif yang terkesan kaku atau substansial-konstekstual dan inklusif yang akomodatif. Dalam pemahaman literalis-tekstual, maknamakna tersirat yang terkandung dalam al-Qur'an dan Hadis cenderung dipinggirkan. Keadaan ini justru problematis, karena cara berpikir seperti ini abai terhadap konteks di mana dan kapan teks al-Qur'an dan Hadis tersebut turun. Nazih Ayubi menjelaskan:

"Percaya akan sifat Islam yang sempurna dan menyeluruh sehingga, menurut mereka, Islam meliputi tiga " $\mathrm{D}$ " yang terkenal itu (dīn, dunyā, dan dawlah). .. (karena itu) Islam adalah sebuah totalitas yang padu yang menawarkan pemecahan terhadap semua masalah kehidupan. Islam harus diterima keseluruhannya, dan harus diterapkan dalam keluarga, ekonomi dan politik. (bagi kalangan muslim ini) realisasi sebuah masyarakat Islam dibayangkan dalam penciptaan sebuah negara Islam, yakni sebuah "negara ideologis" yang didasarkan kepada ajaran-ajaran Islam yang lengkap. 5

Dalam pandangan literalistekstualis gagasan tentang Islam dan Negara merupakan satu kesatuan atau sunnatullah, karena manusia dan alam semesta merupakan ciptaan Tuhan. Oleh karenanya ketundukan dan kepatuhan dalam kehidupan harus didasarkan pada hukum-hukum Tuhan serta diwujudkan dalam sebuah "negara Islam". Memisahkan agama dengan negara sama saja dengan melawan kehendak Tuhan. ${ }^{6}$ Argumen ini dikuatkan dengan ayat al-Qur'an, misalnya dalam surat al-Māidah ayat 44; ... Barangsiapa yang tidak memutuskan menurut apa yang diturunkan Allah, Maka mereka itu adalah orang-orang yang kafir. Maka dari itu mendirikan negara Islam adalah wajib. Menurut pandangan ini kedaulatan absolut hanyalah Allah semata, bila ada yang mengakui kedaulatan lain selain kepada Allah maka ia telah jatuh dalam kemusyrikan. ${ }^{7}$ Oleh karena itu sistem pemerintahan lain selain sistem pemerintahan Islam haruslah ditolak dan ditentang karena telah mengakui kedaulatan selain Allah. Pandangan ini terutama diperjuangkan oleh Sayyid Qutb.8

\footnotetext{
${ }^{5}$ Nazih Ayubi, Political Islam: Religion and Politics in the Arab World (London and New York: Routledge, 1991). 63-64.

${ }^{6} \mathrm{Abu}$ 'Ala Al-Maududi, The Islamic State (Birmingham: UK Islamic Mission Dakwah Center, 1994). 158

${ }^{7}$ John L. Esposito dan John O. Vol., Islam and Democracy (New York: Oxford University Press, 1996). 19 dalam Ahmad Ali Nurdin, "Kaji Ulang Konsep Hubungan Islam Dan Demokrasi," Review Politik 6, no. 1 (2016). 9.

${ }^{8}$ Rahman, M. Taufiq. "Keadilan sosial dalam pemikiran barat dan islam: Studi Komparatif atas Pemikiran John Rawls dan Sayyid Qutb." (2012). http://digilib.uinsgd.ac.id/13066/1/KEADILAN\%20 SOSIAL\%20DALAM\%20PEMIKIRAN\%20BARA T\%20DAN\%20ISLAM.pdf
} 
Sedangkan menurut paham substansial-konstektual Islam tidak mempunyai konsep baku dalam bernegara atau sistem politik. Bahkan istilah negara (dawlah) sama sekali tidak terdapat dalam al-Qur'an. Menurut paham ini al-Qur'an hanya menekankan nilai-nilai yang bersifat etis mengenai aktifitas sosial dan politik umat manusia. Nilai-nilai tersebut mencakup prinsip-prinsip tentang keadilan, kesamaan, persaudaraan, dan kebebasan. ${ }^{9}$ Maka dari itu selama nilai-nilai dan prinsipprinsip tersebut telah tercapai dalam suatu negara, apapun bentuk negara tersebut maka ajaran Islam telah terpenuhi. Salah satu bukti otentikhistoris yang menjadi landasan dalam paham ini adalah Piagam Madinah (Mìtsāq al-Madinah) yang menyatakan bahwa prinsip dan nilai-nilai keislaman secara substantif telah terwujud. Kedua paham di atas sepakat bahwa syariat adalah cara hidup yang wajib diimplementasikan bagi seorang muslim, namun penerapan dan pemahaman terhadapnya begitu berbeda.

Perbedaan dalam mengimplementasikan syariah dapat dilihat dari bentuk-bentuk negara yang mayoritas penduduknya beragama Islam saat ini. Misalnya saja Arab Saudi yang mayoritas penduduknya 100\% beragama Islam memiliki bentuk negara monarki absolut yang diperintah oleh seorang raja dengan sistem hukum Islam bermadzhab Hambali. Berbeda dengan Yaman yang tidak berbentuk monarki tetapi republik dan tidak menjadikan hukum Islam sebagai hukum positif tetapi

\footnotetext{
${ }^{9}$ Ahmad Syafi'i Ma'arif, Islam as The Basis of State: A Study of the Islamic Political Ideas as Reflected in the Constituent Assembly Debates in Indonesia (Chicago, 1983). 23.
}

menjadi salah satu sumber hukum. Mereka menganggap bahwa memformalkan hukum Islam dapat menjadi salah satu faktor pemicu konflik horizontal karena banyaknya madzhab dalam menginterpretasikan syariah. ${ }^{10}$

\section{Perdebatan Golongan Islam dan Nasionalis dalam Merumuskan Ideologi Negara}

Peran Islam sebagai spirit gerakan sosial dan gagasan politik tidak diragukan lagi dalam merebut kemerdekan Indonesia. Sejak kemunculan Sarekat Islam (SI) yang dipelopori oleh H.O.S. Tjokroaminoto, H. Agus Salim dan Abdoel Moeis semangat perjuangan kaum muslimin dalam memerdekakan Indonesia mendapatkan momentumnya. Meskipun dalam perjalanannya mengalami kemerosotan akibat para elitnya yang tidak mampu menyelesaikan perbedaan pandangan di antara mereka juga adanya ideologi Marxisme yang menyusup dalam pergerakan itu namun ide-ide keislaman tetaplah hadir dalam mengawal Indonesia ke gerbang kemerdekaannya. ${ }^{11}$

Di masa awal kemerdekaan, ideologi Islam mengalami persinggungan dengan ideologi nasionalis. Ideologi Islam yang digagas oleh Agus Salim dan M. Natsir menyebutkan bahwa kemerdekaan merupakan jalan pengabdian kepada Allah, oleh karenanya negara Islam merupakan suatu keharusan agar hukum Islam dapat dilaksanakan dan

\footnotetext{
${ }^{10}$ As'ad Said Ali, Negara Pancasila: Jalan Kemaslahatan Berbangsa (Jakarta: Pustaka LP3ES Indonesia, 2009).xi.

${ }^{11}$ Bahtiar Effendy, Islam Dan Negara: Transformasi Gagasan Dan Praktik Politik Islam Di Indonesia (Jakarta: Demokrasi Project, 2011). 72.
} 
ditegakkan. Sedangkan menurut Soekarno yang berpaham nasionalis, ultimate goal dalam kemerdekaan haruslah diisi dengan rasa cinta tanah air. Perdebatan dalam mengisi ideologi negara begitu tampak dan tajam. Namun demikian, walaupun Soekarno cenderung berpaham nasionalis tetapi jiwa keislaman tetap terpatri dalam dirinya dengan mengungkapkan bahwa yang paling penting adalah bagaimana "api" atau "semangat" Islam tetap berkobar, walaupun negaranya sekuler, bila api dan semangat Islam tetap berkobar niscaya Islam pula negara itu. ${ }^{12}$ Perdebatan tajam dalam mengisi ideologi negara terlihat dari sidang BPUPKI tanggal 28 Mei-1 Juni 1945 antara Soepomo yang berpaham nasionalis dengan Ki Bagus Hadikoesomo dari paham IslamMuhammadiyah. Soepomo dalam pidatonya menyampaikan gagasan tentang nasionalisme sebagai ideologi negara:

Memang di sini terihat ada dua paham; paham anggota-anggota ahli agama, yang menganjurkan supaya Indonesia didirikan sebagai negara Islam, dan anjuran lain, sebagai telah dianjurkan oleh Tua Moh Hatta, ialah negara persatuan nasional yang memisahka urusan negara dan urusan Islam, dengan lain perkataan: Bukan negara Islam. ${ }^{13}$

Sebagai seorang nasionalis, Soepomo menolak berdirinya negara Islam dengan argumentasi yang cukup

\footnotetext{
${ }^{12}$ Ali, Negara Pancasila: Jalan Kemaslahatan Berbangsa. 155.

13 Safruddin Bahar, Ananda B Kusuma, Nannie Hudawati, Risalah Sidang Badan Penyelidik UsahaUsaha Persiapan Kemerdekaan Indonesia (BPUPKI), Panitia Persiapan Kemerdekaan Indonesia (Jakarta: Sekretariat Negara Republik Indonesia, 1995), hal. 38.
}

meyakinkan untuk mendamaikan agama dan negara. Menurutnya, harus ada dibedakan antara "negara Islam" dan "Negara berdasarkan cita-cita luhur dari agama Islam." Dalam negara Islam agama tidak bisa dipisahkan dari negara, negara adalah agama dan agama adalah negara keduanya bersatu padu. Permasalahan yang timbul dari konsep ini adalah bahwa "masih ada pertentangan pendirian tentang bagaimana seharusnya bentuk hukum negara, jadi seandaikan kita mendirikan negara Islam, pertentangan akan timbul pula di masyarakat kita. Belum lagi soal agama-agama kecil. Walaupun demikian ia tidak setuju bila Indonesia menjadi negara yang tidak relijius. Oleh karenanya, maka "negara nasional yang bersatu itu akan memelihara budi pekerti kemanusiaan yang luhur, akan memegang teguh cita-cita moral rakyat yang luhur, hendaknya Indonesia juga memakai dasar moral yang luhur, yang juga dianjurkan pula oleh agama Islam." Dari kata-kata tersebut dapat disimpulkan bahwa negara Indonesia menjadikan agama sebagai sumber moral yang luhur dalam mencapai kesejahteraan dan kemanusiaan yang dicita-citakannya.

Puncak perdebatan tersebut mulai mereda setelah Soekarno mengusulkan Pancasila sebagai dasar negara. Usulan ini adalah jalan kompromi yang harus diambil untuk mendamaikan antara kaum relijius dan nasionalis dengan salah satu prinsipnya yaitu Ketuhanan. Negara Indonesia haruslah menjadi negara yang ber-Tuhan tetapi juga Indonesia bukan negara Agama. Kaum relijius dan nasionalis sepakat dalam hal ini. Pancasila akhirnya menjadi usulan yang masuk dalam rancangan 
Mukaddimah UUD 1945 oleh Panitia Kecil yang kemudian rancangan tersebut diperbaiki dan disempurnakan. Butir-butir Pancasila yang digagas oleh Soekarno sama seperti Pancasila yang kita kenal sekarang kecuali pada sila pertama yang berbunyi: "Ketuhanan dengan kewajiban menjalankan syari'at Islam bagi pemeluk-pemeluknya." Rumusan tersebut akhirnya dikenal sebagai "Piagam Jakarta" yang disahkan pada tanggal 11 Juli 1945.

Kendatipun Pancasila telah sepakat dirumuskan sebagai dasar negara, namun kelompok religius yang diwakili oleh Ki Bagus Hadikoesoemo mengusulkan untuk menghilangkan kata "bagi pemeluk-pemeluknya" pada sila pertama sehingga menjadi "Ketuhanan dengan kewajiban menjalankan syariat Islam". Lebih jauh lagi, Wahid Hasyim mengusulkan supaya Presiden dan Wakil Presiden haruslah beragama Islam dan agama negara adalah agama Islam. Perdebatan pun kembali pecah, khususnya dari kalangan Kristen yang diwakili oleh Johanes Latuharhary menolak piagam Jakarta tersebut karena bertentangan dengan adat Maluku, sedangkan A.A. Maramis menyetujuinya.

Pada tanggal 18 Agustus 1945, terjadi perkembangan politik yang signifikan di mana kelompok relijius dari agama Kristen Katolik dari bagian Timur Indonesia merasa tidak cocok dengan Piagam Jakarta. Mereka mengancam akan memisahkan diri dari Indonesia bila Piagam Jakarta tersebut disahkan. Pendapat ini direspon oleh Bung Hatta dengan melobi kalangan relijius Islam dari Aceh yang diwakili oleh Teuku M Hasan agar meyakinkan $\mathrm{Ki}$ Bagus Hadikoesoemo untuk berlapang dada supaya "tujuh kata dalam sila pertama" (kewajiban menjalankan syariat Islam bagi pemeluk-pemeluknya) dihapus dan keharusan Presiden Indonesia beragama Islam dicoret. Ki Bagus menyetujui hal ini tetapi tujuh kata tersebut mesti diganti dengan kata-kata "Yang Maha Esa" dengan demikian prinsip sila pertama bernuansa "tawhid". Akhirnya perubahan tersebut kemudian disetujui oleh oleh kalangan non-muslim. ${ }^{14}$ Meskipun Pancasila sebagai dasar negara Indonesia dinyatakan sudah final tetapi tarik menarik dalam mewarnai ideologi kebangsaan antar kedua kubu ini masih terus berlanjut hingga saat ini.

\section{Pandangan al-Habib Muhammad Rizieq bin Husain Shihab tentang Pancasila}

Landasan historis pemberlakuan syariat Islam di Indonesia menurut Habib Rizieq didasarkan pada masa kerajaan-kerajaan Islam di Nusantara yang telah lebih dulu melakukannya. Ia memberi contoh secara spesifik pada Kesultanan Aceh Darussalam pada abad ke 16 yang dipimpin oleh Sultan 'Alauddin Ri'ayatsyah al-Qahhar yang saat itu Qādhi Malikal-'Ādil (Hakim Agung) telah menjatuhi hukuman pada Raja Linke berupa kewajiban untuk membayar diyat karena telah membunuh adik tiri Sultan. Contoh lainnya adalah di masa kepemimpinan Sultan Iskandar Muda telah menjatuhi hukuman rajam pada anaknya karena terbukti melakukan perzinahan dengan isteri bangsawan istana. Argumen lain yang dijadikan landasannya ialah di masa kolonial hukum yang berlaku menurut ahli hukum Belanda LWC. Van den Berg adalah hukum agama tetapi hal ini ditentang oleh ahli lain

${ }^{14}$ Ali. 160-166 
yaitu Cornelis Van Vollenhoven dan Snouck Hurgronje (ahli keislaman) yang menyatakan bahwa hukum adatlah yang berlaku. Untuk mengatasi hal ini di tahun 1937 pemerintah Hindia-Belanda akhirnya memutuskan untuk mereduksi berlakunya hukum Agama. ${ }^{15}$

Seiring dengan kemerdekaan Indonesia, para pendiri bangsa (founding fathers) berkomitmen untuk membentuk sebuah konsensus dasar yang menjadi pedoman bagi bangsa Indonesia sebagai dasar hidup berbangsa dan bernegara. Pancasila, sebagai common platform bangsa Indonesia yang dikenal saat ini dalam pandangan Habib Rizieq dinilai telah menyeleweng dari yang seharusnya. Dalam tesisnya Habib Rizieq menyimpulkan:

1. Bahwasanya secara substantif, Prof. Mr. Yamin adalah orang yang pertama menghurai isi kandungan Pancasila dengan istilah Lima Dasar Negara, walaupun beliau tidak menyebut secara jelas istilah Pancasila. Namun secara formalistis, Ir. Soekarno adalah orang yang pertama kali menyebut secara jelas istilah Pancasila sebagai Dasar Negara. 2. Bahawasanya Pancasila sebagai istilah dengan erti Lima Dasar atau kalimat yang terdiri dari dua kata, Panca dan Sila, merupakan bahagian dari budaya pribumi Indonesia. Namun Pancasila sebagai istilah dengan erti Lima Dasar Negara Indonesia bukan merupakan bahagian dari budaya pribumi

\footnotetext{
${ }^{15}$ al-Habib Muhammad Rizieq bin Husain Shihab, "Pengaruh Pancasila Terhadap Penerapan Syariah Islam Di Indonesia" (Universiti Malaya, 2012). 167.
}

Indonesia, melainkan merupakan hasil galian dari ajaran Islam dan budaya Barat Cina - India. 3. Bahwasanya Rumusan Pancasila I adalah rumusan Pancasila yang paling tulen, kerana merupakan Konsensus Nasional yang pertama kali disepakati oleh para Bapak Penubuh (Founding Father) Negara Indonesia, samada dari Kelompok Islam mahu pun dari Kelompok Sekuler, dan dihasilkan melalui musyawarah yang penuh rasa kekeluargaan dan saling pengertian, lintas sektoral tanpa campurtangan asing, serta melibatkan berbagai komponen bangsa secara representative, yang sekaligus menjadi putusan rasmi sidang BPUPKI. 4. Bahawa Rumusan Pancasila I iaitu Pancasila Piagam Jakarta berdasarkan Dekrit Presiden 5 Julai $1959 \quad$ sepatutnya dikuatkuasa, sehingga tuntutan pengembalian Piagam Jakarta saat ini sudah sesuai dengan isi Dekrit tersebut, apalagi Dekrit tersebut sampai saat ini tetap berlaku dan tidak pernah dibatalkan. 5. Bahawa semua rumusan Pancasila yang lahir setelah Rumusan Pancasila I, tidak tulen, bahkan penuh rekayasa dan permainan politik yang tidak sehat, sehingga hanya merupakan penyelewengan dari kesepakatan para Bapak Penubuh (Founding Father) Negara Indonesia, sekaligus merupakan pengkhianatan terhadap Konsensus Nasional. ${ }^{16}$

${ }^{16}$ Shihab. 102-104 
Yang menjadi titik tekan dalam kesimpulan tersebut adalah bahwa pada awalnya Pancasila yang digagas oleh Soekarno adalah bukan murni digali dari nilai-nilai luhur bangsa Indonesia tetapi merupakan saduran dari gagasan para tokoh dunia saat itu seperti yang disebutkan dalam pidato Soekarno. Pada tanggal 1 Juni 1945 Soekarno menggagas lima dasar negara yaitu: (1) Kebangsaan Indonesia, (2) Internasionalisme atau Peri Kemanunisaan, (3) Mufakat atau Demokrasi, (4) Kesejahteraan Sosial, (5) Ketuhanan. Dalam pidatonya Soekarno berkata:

...Bangsa Tionghoa dahulu banyak yang kena penyakit kosmopolitisme, sehingga mereka berkata bahwa tidak ada bangsa Tionghoa, tidak ada bangsa Nippon, tidak ada bangsa India, tidak ada bangsa arab, tetapi semuanya "menscheid", "peri kemanusiaan". Tetapi Dr. Sun Yat Sen bangkit, memberi pengajaran kepada rakyat Tionghoa, bahwa ada kebangsaan Tionghoa! Saya mengaku, pada waktu saya berumur 16 tahun, duduk di bangku sekolah H.B.S. di Surabaya, saya dipengaruhi oleh seorang sosialis yang bernama $\mathrm{A}$. Baars, yang memberi pelajaran kepada saya, - katanya : jangan berfaham kebangsaan, tetapi berfahamlah rasa kemanusiaan sedunia, jangan mempunyai rasa kebangsaan sedikitpun. Itu terjadi pada tahun 1917. Tetapi pada tahun 1918, alhamdulillah, ada orang lain yang memperingatkan saya, - ialah Dr. Sun Yat Sen! Di dalam tulisannya "San Min Chu I" atau "The Three People's Principles", saya mendapat pelajaran yang membongkar kosmopolitisme yang diajarkan oleh A. Baars itu. Dalam hati saya sejak itu tertanamlah rasa kebangsaan,oleh pengaruh "The Three People's Principles" itu, maka oleh karena itu jikalau seluruh bangsa Tiong-hoa menganggap Dr. Sun Yat Sen sebagai penganjurnya, yakinlah, bahwa Bung Karno juga seorang Indonesia yang dengan perasaan hormat sehormat-hormatnya merasa berterimakasih kepada Dr. Sun Yat Sen, sampai masuk lubang kubur...

Dari penggalan pidato Soekarno di atas Habib Rizieq menyimpulkan bahwa sila pertama yaitu Kebangsaan Indonesia banyak dipengaruhi oleh seorang sosialis. ${ }^{17}$ Sila kedua yaitu peri kemanusiaan, Soekarno mendapatkannya dari kata-kata Mahatma Gandhi:

... Tetapi Tanah Air kita Indonesia hanya satu bahagian kecil saja daripada dunia! Ingatlah akan hal ini!Gandhi berkata : "Saya seorang nasionalis, tetapi kebangsaan saya adalah peri kemanusiaan", "My nationalism is humanity"...18

Pada sila ketiga Soekarno menggagas prinsip musyawarahmufakat yang diambil dari prinsip Islam. Tetapi dalam hal ini Habib Rizieq memandang bahwa musyawarah yang dimaksud Soekarno bukanlah musyawarah dalam kerangka Islam tetapi musyarawah sebagai ciri demokrasi produk pemikiran Barat. Dalam pidato Soekarno disebutkan:

\footnotetext{
${ }^{17}$ Shihab. 54

${ }^{18}$ Shihab. 55
} 
...Untuk pihak Islam, inilah tempat yang terbaik untuk memelihara agama. Kita, sayapun, adalah orang Islam, maaf beribu-ribu maaf keislaman saya jauh belum sempurna, tetapi kalau saudara-saudara membuka saya punya dada, dan melihat saya punya hati, Tuantuan akan dapati tidak lain tidak bukan hati Islam. Dan hati Islam Bung Karno ini, ingin membela Islam dalam mufakat, dalam permusyawaratan. Dengan cara mufakat, kita perbaiki segala hal, juga keselamatan agama, yaitu dengan jalan membicarakan atau permusyawaratan di dalam Badan Perwakilan Rakyat... ${ }^{19}$

Pada sila keempat, Habib Rizieq menganggap bahwa kesejahteraan sosial merupakan gagasan Dr. Sun Yat Sen dengan prinsipnya Nasionalisme (Mintsu), Demokrasi (Min Chuan) dan Sosialisme (Min Sheng).

...Prinsip nomor 4 sekarang saya usulkan. Saya di dalam 3 hari ini belum mendengarkan prinsip itu, yaitu prinsip kesejahteraan, prinsip: tidak akan ada kemiskinan di dalam Indonesia Merdeka. Saya katakan tadi: prinsipnya San Min Chu I ialah Mintsu, Min Chuan, Min Sheng: nationalism, socialism...20 democracy,

Di sila kelima, Habib Rizieq memandang bahwa Soekarno berusaha menafsirkan sila tersebut dengan mengakui eksistensi semua Tuhan yang disembah dalam berbagai agama. Namun tidak dipungkiri bahwa

${ }^{19}$ Shihab. 56

${ }^{20}$ Shihab.57. menurutnya pada sila tersebut pula Soekarno mengambil salah satu nilai dalam Islam yang disebut dengan "taqwa" dan "tauhid" atau keesaan Tuhan. Oleh karena itu, menurutnya, sila tersebut adalah nilai Islam bukan berasal nilai dari budaya pribumi Indonesia. Dalam pidato Soekarno disebutkan:

...Prinsip yang kelima hendaknya: Menyusun Indonesia, merdeka dengan bertakwa kepada Tuhan Yang Maha Esa...21

\section{Perumusan Pancasila}

Dalam penelitian habib Rizieq, dari tinjauan historis, Putusan Pancasila sebagai dasar ideologi dan filosofi negara telah mengalami "bongkar pasang". Menurutnya ada lima kali perubahan yang terjadi sejak kemerdekaan Indonesia tahun 1945.

\section{Perumusan Pancasila I}

Perumusan Pancasila I diputuskan oleh panitia kecil yang dibentuk oleh BPUPKI (Badan Penyelenggara Usaha-usaha Kemerdekaan Indonesia) berjumlah sembilan orang yang kemudian disebut PPKI (Panitia Persiapan Kemerdekaan Indonesia), sebagai upaya untuk menyelesaikan perbedaan pendapat yang terjadi dalam sidang BPUPKI yang pertama. Anggota PPKI tersebut adalah:

1. KH. Wahid Hasyim

2. H. Agus Salim

3. Abiekoesno Tjokrosoejoso

4. Abdul Kahar Muzakkir

5. Soekarno

6. Muhammad Hatta

7. Muhammad Yamin

8. Ahmad Soebardjo

9. A.A. Maramis

${ }^{21}$ Shihab.58-59. 
Hasil kesepakatan panitia sembilan tersebut adalah Piagam Djakarta (The Jakarta Charter) yang ditandatangani pada tanggal 22 Juni 1945 oleh seluruh anggota BPUPKI dan dijadikan sebagai pembukaan Undang-Undang Dasar 1945. Isi Piagam Jakarta 22 Juni 1945:

“Bahwa sesungguhnya kemerdekaan itu ialah hak segala bangsa, dan oleh sebab itu maka penjajahan di atas dunia harus dihapuskan karena tidak sesuai dengan peri kemanusian dan peri keadilan. Dan perjuangan pergerakan kemerdekaan Indonesia telah sampailah kepada saat yang berbahagia, dengan selamat sentosa membawa rakyat Indonesia ke depan pintu gerbang Negara Indonesia yang merdeka, bersatu, berdaulat adil dan makmur.

Dari penjelasan di atas, Habib Rizieq menganggap bahwa Piagam Jakarta inilah yang paling otentik dengan alasan:

a) Bahwa rumusan Pancasila yang digagas oleh Soekarno merupakan pendapat pribadi Soekarno dan bukan hasil akhir dari keputusan sidang.

b) Rumusan Pancasila I telah diputuskan melalui sidang BPUPKI sehingga menjadi putusan yang resmi dan sah.

c) Rumusan Pancasila I merupakan rumusan yang disepakati oleh para pendiri bangsa Indonesia.

\section{Perumusan Pancasila II}

Pada tanggal 17 Agustus 1945, atas nama bangsa Indonesia, Soekarno dan Hatta memproklamirkan kemerdekaan bangsa Indonesia dengan membacakan teks Proklamasi. Menurut
Habib Rizieq seharusnya Piagam Jakarta yang dibacakan pada saat itu bukan teks proklamasi karena Piagam Jakarta yang telah disepakati oleh seluruh anggota BPUPKI. Namun status Piagam Jakarta sebagai kesepakatan bersama para pendiri bangsa tetap diakui.

Pada petang harinya Muhammad Hatta didatangi oleh seorang opsir kaigun Jepang (Perwira Angkatan Laut Jepang) yang didampingi oleh seorang juru bahasa bernama Mr. Nisyijima menyampaikan keberatannya dari pihak Kristiani di bagian timur Indonesia atas Piagam Jakarta. Mereka meminta agar kalimat "dengan kewajiban menjalankan syariat Islam bagi pemeluk-pemeluknya" dihapus. Aspirasi ini langsung mendapat respon dari bung Hatta dengan menggelar rapat perubahan yang diadakan keesokan harinya tanggal 18 Agustus 1945. Rapat yag diadakan amat mendadak tersebut hanya dihadiri oleh empat anggota PPKI yaitu, Ir. Soekarno, M. Hatta, Soebardjo dan K.H. Wahid Hasyim. Meski pada akhirnya KH. Wahid Hasyim tidak dapat menghadiri rapat tersebut. Bung Hatta mengusulkan empat poin yaitu:

a) Kata "mukaddimah" diubah menjadi pembukaan.

b) Dalam pembukaan UUD 1945 katakata "berdasarkan ketuhanan dengan menjalankan syariat Islam bagi pemeluk-pemeluknya" diubah menjadi "berdasarkan ketuhanan yang maha esa"

c) Pasal 6 ayat 1 yang berbunyi: "Presiden Indonesia ialah orang Indonesia asli dan beragama Islam" diubah menjadi "Presiden Indonesia adalah orang Indonesia asli."

d) Pasal 29 ayat 1 yang berbunyi: Negara berdasarkan atas Ketuhanan dengan kewajiban menjalankan Syariat 
Islam bagi pemeluk pemeluknya" diubah menjadi "Negara berdasarkan atas Ketuhanan Yang Maha Esa".

Usulan bung Hatta tersebut disetujui oleh anggota PPKI yang hadir saat itu. Menurut habib Rizieq usulan tersebut merupakan usulan kontroversial, karena:

a) Sidang tersebut diselenggarakan secara mendadak dan terburu-buru sehingga keputusan yang dihasilkan tidaklah mencerminkan kesepakatan seluruh anggota BPUPKI.

b) Kedatangan opsir Kaigun Jepang untuk menemui bung Hatta dianggap sebagai cerita yang dibuatbuat karena tidak didukung oleh bukti dan saksi yang kuat. Oleh habib Rizieq peristiwa ini dianggap sebagai upaya menghilangkan "kalimat Islami" dan merubah UUD 1945.

c) Pada awalnya sang Opsir Kaigun Jepang hanya menuntut perubahan kalimat "dengan kewajiban menjalankan syariat Islam bagi pemeluk-pemeluknya." Namun mengapa pada akhirnya semua "kalimat Islami" semuanya dirubah dan dihapus.

d) Kekhawatiran minoritas pihak Kristen seolah lebih penting daripada kekecewaan umat Islam.

e) Seandainya pengakuan bung Hatta tersebut benar adanya, maka perubahan UUD 1945 tersebut telah dicampuri oleh pihak asing yang tidak dikenal.

\section{Perumusan Pancasila III}

Pasca Kemerdekaan Republik Indonesia tanggal 17 Agustus 1945 dan kekalahan pihak Jepang oleh tentara sekutu, Belanda datang kembali untuk menguasai wilayah Indonesia. Dengan mengerahkan agresi militer pertama pada tanggal 27 Juli 1947 dan agresi militer kedua pada tanggal 18 Desember 1948. Pada agresi militer Belanda I, Belanda berusaha menguasai daerah Sumatra dan Jawa dengan tujuan untuk menguasai daerah perkebunan tembakau, tebu, pabrik gula, dan minyak. Atas Tindakan Belanda yang sewenang-wenang ini, Indonesia mengadukannya ke PBB karena Belanda telah melanggar perjanjian Linggarjati ${ }^{22}$. Pada tanggal 15 Agustus 1947 atas tekanan dari Dewan Keamanan PBB, akhirnya pemerintah Belanda menyetujui resolusi untuk mengakhiri pertempuran.

Agresi militer Belanda II terjadi pada tanggal 18 Desember 1948 dengan melakukan serangan ke kota Yogyakarta, ibukota Republik Indonesia saat itu, dan menangkap Soekarno, Moh. Hatta, Sjahrir, dan beberapa tokoh lainnya. Jatuhnya ibukota negara dan penangkapan para tokoh bangsa mengharuskan dibentuknya Pemerintahan Darurat Republik Indonesia yang dipimpin oleh Sjafruddin Prawiranegara di Bukit Tinggi, Sumatera.

Agresi militer Belanda II mengantarkan Indonesia dan Belanda kembali ke meja perundingan atas desakan dari PBB. Maka dari itu

\footnotetext{
${ }^{22}$ Hasil perundingan tersebut menghasilkan 17 pasal yang antara lain berisi:

a. Belanda mengakui secara de facto wilayah Republik Indonesia, yaitu Jawa, Sumatera dan Madura.

b. Belanda harus meninggalkan wilayah RI paling lambat tanggal 1 Januari 1949.

c. Pihak Belanda dan Indonesia Sepakat membentuk negara RIS.

d. Dalam bentuk RIS Indonesia harus tergabung dalam Commonwealth/Persemakmuran Indonesia-Belanda dengan mahkota negeri Belanda sebagai kepala uni.
} 
diadakanlah perjanjian Roem-Royen yang hasilnya memulihkan pemerintahan Republik Indonesia di Yogyakarta. Di samping itu akan diadakan perundingan kembali dalam Konferensi Meja Bundar di Den Haag.

Dalam Konferensi Meja Bundar (KMB) yang diadakan tanggal 23 Agustus - 2 November 1949 Republik Indonesia, Belanda, dan BFO (Bijeenkoomst voor Federal Overleg), negara boneka bentukan Belanda, kembali berunding. Dalam konferensi tersebut Republik Indonesia dan BFO sepakat bahwa republik Indonesia merupakan bagian dari Republik Indonesia Serikat(RIS) yang dinyatakan dalam sebuah piagam persetujuan yang berisi:

Kami bangsa Indonesia semenjak berpuluh-puluh tahun lamanya bersatu padu dalam memperjuangan kemerdekaan, dengan senantiasa berhati teguh berniat menduduki hak-hidup sebagai bangsa yang merdeka berdaulat.

Kini dengan berkat dan rahmat Tuhan telah sampai kepada tingkatan sejarah yang berbahagia dan luhur.

Maka demi ini kami menyusun kemerdekaan kami itu dalam suatu Piagam negara yang berbentuk republik-federasi, berdasarkan pengakuan Ketuhanan Yang Maha Esa, perikemanusiaan, kebangsaan, kerakyatan, dan keadilan sosial.Untuk mewujudkan kebahagiaan kesejahteraan perdamaian dan kemerdekaan dalam masyarakat dan negarahukum Indonesia Merdeka yang berdaulat sempurna.
Dalam rumusan III ini redaksi butir-butir Pancasila telah berubah. Pada rumusan ke-II berbunyi: 1.Ketuhanan yang Maha Esa, Kemanusiaan yang adil dan beradab, Persatuan Indonesia, Kerakyatan yang dipimpin oleh hikmat kebijaksanaan dalam permusyawaratan perwakilan, Keadilan sosial bagi seluruh rakyat Indonesia.Sedangkan pada rumusan ke- III: Ketuhanan Yang Maha Esa, Perikemanusiaan, Kebangsaan, Kerakyatan, dan Keadilan Sosial.

\section{Perumusan Pancasila IV}

Pada rumusan Pancasila IV, pasca Konferensi Meja Bunjar, M. Natsir mengajukan usul intergral yang bertujuan untuk menyatukan Republik Indonesia Serikat (RIS) ke dalam Negara Kesatuan Republik Indonesia. Usul ini kemudian disetujui oleh DPR Federal yang hadir saat itu. Pada tanggal 19 Juli 1950 RIS resmi menjadi NKRI. Keesokan harinya UUD Sementara NKRI dibuat dan dikukuhkan pada tanggal 14 Agustus 1950. Isi UUD Sementara NKRI tersebut adalah berikut:

"Bahwa sesungguhnya kemerdekaan itu ialah hak segala bangsa, dan oleh sebab itu maka penjajahan di atas dunia mesti dihapuskan, kerana tidak sesuai dengan peri kemanusiaan dan peri keadilan. Dan perjuangan pergerakan kemerdekaan Indonesia telah sampailah kepada saat yang berbahagia, dengan selamat sentosa membawa rakyat Indonesia ke depan pintu gerbang Negara Indonesia, yang merdeka, bersatu, berdaulat, adil dan makmur.

Dengan berkat dan rahmat Tuhan telah sampai kepada tingkatan sejarah yang berbahagia dan 
luhur.Maka demi ini kami menyusun kemerdekaan kami itu dalam suatu piagam negara yang berbentuk Republik-Federasi, berdasarkan pengakuan : Ketuhanan Yang Maha Esa, Perikemanusiaan, Kebangsaan, Kerakyatan, dan Keadilan Sosial. Untuk mewujudkan kebahagiaan, kesejahteraan, perdamaian, dan kemerdekaan dalam masyarakat dan negara hukum Indonesia merdeka yang berdaulat sempurna"

Perubahan UUD sementara ini, jika diteliti redaksinya merupakan gabungan dari Mukaddimah Piagam Jakarta 22 Juni 1945 dan bagian kedua dari Konstitusi RIS 1949.

\section{Perumusan Pancasila V}

Setelah Republik Indonesia Serikat (RIS) bergabung ke Negara Kesatuan Republik Indonesia (NKRI), sesuai UUD Sementara tahun 1950 bab $\mathrm{V}$ pasal 134 penggantian UndangUndang Sementara harus segera dilakukan untuk merumuskan Undang-Undang Dasar Republik Indonesia. Namun nyatanya sejak sidang pertama tanggal 10 November 1956 hingga 1958, anggota konstituante belum juga dapat merumuskan Undang-Undang Dasar. Adanya desakan dari masyarakat agar sebaiknya Undang-Undang Dasar dikembalikan pada UUD 1945. Oleh karena itu Soekarno menyampaikan usulan ini di sidang konstituantepada 22 April 1959. Usulan ini mendapat tanggapan dari para anggota dengan mengadakan pemungutan suara. Hasilnya, sebanyak 269 anggota setuju dan 199 lainnya tidak setuju. Walaupun pihak yang setuju lebih banyak dari yang tidak setuju, namun jumlah suara tidak mencapai kuorum yaitu jumlah 2/3 suara dari seluruh anggota yang hadir. Pemungutan suara kembali dilakukan, namun hasilnya tetap tidak mencapai kuorum.

Menurut habib Rizieq, dalam sidang tersebut para anggota sidang terpecah dalam dua faksi besar yaitu faksi Islam dan faksi sekuler. Faksi Islam terdiri dari Masyumi, Nahdhatul Ulama, Perti, PSII, Akui, Gerpis dan Penyaluran. Faksi Islam menginginkan agar rumusan Pancasila kembali pada Piagam Jakarta. Sedangkan faksi sekuler yang terdiri dari PNI, PKI, Pertindo, PSI, Partai Katholik, IPKI dan beberapa partai kecil menginginkan agar rumusan Pancasila kembali ke Undang-Undang Dasar tanggal 18 Agustus 1945 (rumusan kedua). ${ }^{23}$ Untuk menyelamatkan persatuan dan negara maka Presiden Soekarno menengahi keduanya dengan mengeluarkan dekrit 5 Juli 1959. Isi dekrit tersebut adalah:

DEKRET PRESIDEN REPUBLIK INDONESIA/PANGLIMA TERTINGGI ANGKATAN PERANGTENTANGKEMBALI KEPADA UNDANG-UNDANG DASAR 1945

Dengan rachmat Tuhan Jang Maha Esa,

KAMI PRESIDEN REPUBLIK INDONESIA/PANGLIMA TERTINGGI ANGKATAN PERANG

Dengan ini menjatakan dengan chidmat:

Bahwa andjuran Presiden dan Pemerintah untuk kembali kepada Undang-Undang Dasar 1945 jang disampaikan kepada

${ }^{23}$ Shihab. 86 
segenap rakjat Indonesia dengan amanat Presiden pada tanggal 22 April 1959 tidak memperoleh keputusan dari Konstituante sebagaimana ditentukan dalam Undang-Undang Dasar Sementara;

Bahwa berhubung dengan pernjataan sebagian besar anggota-anggota Sidang Pembuat Undang-Undang Dasar untuk tidak lagi menghadiri sidang. Konstituante tidak mungkin lagi menjelesaikan tugas jang dipertjajakan oleh rakjat kepadanja;

Bahwa hal jang demikian menimbulkan keadaan-keadaan ketatanegaraan jang membahajakan persatuan dan keselamatan Negara, Nusa, dan Bangsa, serta merintangi pembangunan semesta untuk mencapai masjarakat jang adil makmur;

Bahwa dengan dukungan bagian terbesar rakjat Indonesia dan didorong oleh kejakinan kami sendiri, kami terpaksa menempuh satu-satunja djalan untuk menjelamatkan Negara Proklamasi;

Bahwa kami berkejakinan bahwa Piagam Djakarta tertanggal 22 Djuni 1945 mendjiwai UndangUndang Dasar 1945 dan adalah merupakan suatu rangkaian kesatuan dengan Konstitusi tersebut,

Maka atas dasar-dasar tersebut di atas,

KAMI PRESIDEN REPUBLIK INDONESIA/PANGLIMA TERTINGGI ANGKATAN PERANG

Menetapkan pembubaran

Konstituante;
Menetapkan Undang-Undang Dasar 1945 berlaku lagi bagi segenap bangsa Indonesia dan seluruh tumpah darah Indonesia terhitung mulai hari tanggal penetapan dekret ini dan tidak berlakunja lagi Undang-Undang Dasar Sementara.

Pembentukan Madjelis Permusjawaratan Rakyat Sementara, jang terdiri atas anggota-anggota Dewan Perwakilan Rakjat ditambah dengan utusan dari daerahdaerah dan golongan-golongan serta pembentukan Dewan Pertimbangan Agung Sementara akan diselenggarakan dalam waktu sesingkat-singkatnja.

Ditetapkan di Djakarta pada tanggal 5 Djuli 1959

Atas nama Rakjat Indonesia Presiden Republik Indonesia/Panglima Tertinggi Angkatan Perang SOEKARNO

Dari Dekrit Presiden Soekarno di atas, Habib Rizieq menyimpulkan bahwa rumusan Pancasila ke-V merupakan rumusan Pancasila ke-II yang dijiwai dengan rumusan Pancasila ke-I (Piagam Jakarta) bahkan keduanya tak bisa dipisahkan. Bahwa walaupun secara redaksi berbeda namun rumusan Pancasila ke-I menjiwai seluruh rumusan sesudahnya, karena rumusan Pancasila I adalah rumusan yang paling otoritatif dan disusun serta disepakati oleh seluruh para pendiri bangsa sedangkan rumusan sesudahnya adalah rumusan yang kontroversial karena adanya campur tangan pihak asing. ${ }^{24}$

\section{Kritik atas Pandangan Habib Rizieq tentang Pancasila}

${ }^{24}$ Shihab. 87. 
Dari paparan di atas, telah dijabarkan perspektif Habib Rizieq tentang Pancasila yang ditinjau di aspek historis. Maka dari itu dapat disimpulkan poin-poin utama dari pandangan beliau; 1. Pancasila yang digagas Soekarno bukanlah murni berasal dari nilai-nilai luhur bangsa Indonesia, 2. Rumusan Piagam Jakarta adalah Undang-Undang Dasar yang paling tulen dan otoritatif karena telah disepakati dan disetujui oleh seluruh anggota BPUPKI. Adapun rumusan setelahnya tidaklah sah karena telah banyak dicampuri oleh pihak asing, 3. Dekrit 5 Juli 1959 belum dicabut, oleh karena itu seharusnya yang menjadi Undang-Undang Dasar adalah rumusan Piagam Jakarta.

Di poin pertama, Habib Rizieq memandang bahwa rumusan Pancasila yang digagas Soekarno bukanlah berdasarkan nilai-nilai bangsa Indonesia. Habib Rizieq melandaskan pandangannya pada pidato-pidato yang Soekarno di sidang BPUPKI yang mengutip tokoh-tokoh sosialis. Menurut penulis, mengutip salah satu pandangan tokoh dunia dalam merumuskan ideologi negara adalah hal yang sah-sah saja karena pidato Soekarno saat itu masih berupa usulan dan masih dapat diperdebatkan. Apakah usulan itu diterima ataupun ditolak merupakan hasil dari rapat yang dihadiri oleh berbagai golongan, baik dari golongan Islam maupun nasionalis. Bukti kongkretnya adalah perubahan redaksi yang sudah final ternyata dapat diterima oleh semua kalangan.

Pada poin kedua, Habib Rizieq memandang bahwa rumusan Pancasila I atau Piagam Jakarta merupakan rumusan yang paling tulen. Menurut penulis, Undang-Undang Dasar yang didalamnya memuat butir-butir Pancasila yang menjadi ideologi negara merupakan sebuah proses historis yang tak dapat dihindari serta sesuai dengan semangat zaman yang dihadapi. Perubahan-perubahan yang terjadi dalam rumusan Pancasila telah mengalami pergulatan ideologi yang panjang dan alot serta pada akhirnya dapat dilalui dengan penuh keberanian dan kebijaksaan dari para pendiri bangsa dengan menerima segala keputusan yang telah disepakati. Adapun yang perlu digarisbawahi pada perubahan butir pertama dalam Pancasila adalah untuk menjaga semangat persatuan bangsa Indonesia tanpa ada tendensi dan diskriminasi suku, ras, agama dan golongan. Oleh karena itu penilaian akan adanya intrik politik yang picik dibalik perubahan sila pertama tersebut kiranya tidak dapat dipertanggungjawabkan. Pada poin ini bung Hatta selaku inisiator dalam perumusan Pancasila yang kedua telah berkontribusi besar dalam menjaga persatuan bangsa Indonesia. Bung Hatta menulis dalam otobiografinya:

"Karena begitu serius rupanya, esok paginya, tanggal 18 Agustus 1945, sebelum sidang Panitia Persiapan bermula, kuajak Ki Bagus Hadikoesoemo, Wahid Hasyim, Mr. Kasman Singodemedjo, dan Mr. Teuku Hasan dari Sumatera mengadakan suatu rapat pendahuluan untuk membicarakan masalah itu. Supaya kita jangan pecah sebagai bangsa, kami mufakat untuk menghilangkan bagian kalimat yang menusuk hati kaum Kristen itu dan menggantinya dengan "Ket-Tuhanan Yang maha Esa." 
Apabila suatu masalah yang serius dan bisa membahayakan keutuhan negara dapat diatasi dalam sidang kecil yang lamanya kurang dari 15 menit, itu adalah suatu tanda bahwa pemimpinpemimpin tersebut pada waktu itu benar-benar mementingkan nasib dan persatuan Indonesia."

"Pada waktu itu kami menginsafi bahwa semangat Piagam Jakarta tidak lenyap dengan menghilangkan perkataan "KeTuhanan dengan kewajiban menjalankan syariat Islam bagi pemeluk-pemeluknya" dan menggantikannya dengan "KeTuhanan Yang Maha Esa". Dalam negara Indonesia yang kemudian memakai semboyan Bhinneka Tunggal Ika, tiap-tiap peraturan dalam kerangka syariat Islam, yang hanya mengenai orang Islam, dapat dimajukan sebagai rencana undang-undang ke DPR, yang setelah diterima oleh DPR mengikat umat Islam Indonesia. Dengan cara begitu, lambat laun terdapat bagi umat Islam Indonesia suatu sistem syariat Islam yang teratur dalam undangundang, berdasarkan Al Quran dan hadis, yang sesuai pula dengan keperluan masyarakat Islam sekarang. Orang tidak perlu mengambil saja dari syariat Islam yang berlaku dahulu di negerinegeri Arab dalam abad ke-8, ke9 , atau ke-10 yang ada waktu itu sesuai pula dengan keadaan masyarakat di situ. ${ }^{25}$

\footnotetext{
${ }^{25}$ Mohammad Hatta, Menuju Gerbang Kemerdekaan: Untuk Negeriku, Sebuah Otobiografi (Jakarta: Kompas, 2014).
}

Dari penelusuran penulis ditemukan data-data bahwa Habib Rizieq memiliki agenda untuk menerapkan syariat Islam secara keseluruhan yang dapat merubah sistem ketatanegaraan dan hukum di Indonesia. Gagasan yang sering disampaikan dalam tulisan-tulisan serta ceramah-ceramah keagamaannya adalah "NKRI Bersyariah" yaitu penerapan syariah secara keseluruhan di semua aspek kehidupan berbangsa dan bernegara. Dalam salah satu pidatonya menyebutkan:

“Bagi NKRI BERSYARIAH bahwa Tathbiq Syariah di Indonesia adalah harga mati yang tidak bisa ditawar, karena Indonesia adalah Negara Tauhid yang berdasarkan kepada Ketuhanan Yang Maha Esa, sehingga Syariat Islam harus diterapkan di tengah masyarakat muslim Indonesia dalam kehidupan berbangsa dan bernegara, tanpa mengebiri hak beragama kaum minoritas mana pun." 26

Di samping itu, pemberlakuan sistem khilafah merupakan salah satu aspek penerapan syariah dalam konteks ini. Indonesia sebagai negara "Pancasila" tentunya tidak menganut asas ini, maka dari itu dalam kerangka berfikir ini Indonesia adalah negara yang tidak berdasarkan syariat Islam. Dalam pernyataanya habib Rizieq berkata:

"Bagi NKRI BERSYARIAH bahwa Sistem Khilafah adalah Sistem yang harus ditegakkan, apalagi sudah berhasil membuktikan diri selama 13 (tiga belas) abad lebih

\footnotetext{
${ }^{26}$ Forum Diskusi Santri FPI, "NKRI Bersyariah vs Islam Nusantara," 2015, http://www.suaraislam.com/read/kolom/habib-rizieqsyihab/15955/NKRI-Bersyariah-vs-IslamNusantara.
} 
sebagai sistem terbaik yang sukses memimpin Dunia. Dan Penegakan Khilafah adalah sesuatu yang pasti akan terwujud, setidaknya saat kedatangan Imam Mahdi sebagaimana dikabarkan oleh Nabi SAW, sehingga perjuangan Penegakan Khilafah sepanjang zaman akan selalu menjadi andil penting untuk membuka jalan bagi kedatangan Sang Imam." 27

Menurut Habib Rizieq negara Indonesia adalah negara sekuler. Namun demikian, meskipun Indonesia tidak menganut sistem hukum Islam nyatanya sebagai negara "Pancasila", Indonesia tetap mengakomodir aspirasi-aspirasi umat Islam misalnya dalam UU No.2 Tahun 1989 tentang sistem pendidikan nasional yang mengakomodasi pendidikan agama, UU No.7 tahun 1989 tentang peradilan agama, dan UU No. 7 tahun 1992 tentang Perbankan yang mengakomodasi beroperasinya bank dengan sistem bagi hasil (perbankan syariah), ${ }^{28}$ dan lain sebagainya. Namun nampaknya hal tersebut tidak cukup bagi Habib Rizieq, baginya hukum negara pun perlu disyariatkan. Penulis berasumsi bahwa Habib Rizieq ingin melegitimasi gagasan formalisasi syariah Islam dengan mengacu pada Piagam Jakarta dan dalihnya adalah bahwa dekrit 5 Juli 1959 oleh Presiden Soekarno belum dicabut sehingga seharusnya Piagam Jakartalah yang berlaku saat ini.

Menurut Yusril, dekrit tahun 1959 adalah produk revolusi di luar hukum

${ }^{27} \mathrm{FPI}$.

${ }^{28}$ Masykuri Abdillah, "Hubungan Agama Dan Negara Dalam Konteks Modernisasi Politik Di Era Reformasi," Ahkam IX (2013):. 250. dan konstitusi (inkonstitusional). Sebuah dekrit diakui jika keberadaannya mendapat dukungan politik yang cukup dari rakyat, terutama dari tentara dan parlemen. ${ }^{29}$ Bila dilihat dari aspek historis, Dekrit 5 Juli 1959 hadir dalam kondisi darurat karena majelis konstintuante tidak dapat merumuskan Undang-Undang saat itu. Oleh karena itu apabila kondisi darurat itu telah dilalui maka sebuah dekrit hanya sebuah fakta sejarah saja dan kemudian yang berlaku adalah instrumen hukum yang konstitusional. Pada alinea ini maka poin ketiga dari pernyataan Habib Rizieq telah terjawab.

\section{KESIMPULAN}

Al-Habib Muhammad Rizieq bin Husein Shihab menganut paham literalis-tekstualis dalam memaknai syariah. Menurutnya penerapan syariah haruslah total diimplementasikan dalam kehidupan berbangsa dan bernegara. Adanya gagasan bahwa Pancasila yang diakui oleh seluruh bangsa Indonesia saat ini adalah inkonstitusional merupakan kesalahpahaman Habib Rizieq dalam memahami dekrit Presiden Soekarno tahun 1959.

\footnotetext{
${ }^{29}$ IS, "Yusril: Dekrit Absah Jika Diterima Rakyat," 2013, https://www.gatra.com/hukum-1/24814yusril-dekrit-absah-jika-diterima-rakyat.html.
} 


\section{DAFTAR PUSTAKA}

Abdillah, Masykuri. "Hubungan Agama Dan Negara Dalam Konteks Modernisasi Politik Di Era Reformasi." Ahkam IX (2013): 247-58.

Al-Maududi, Abu 'Ala. The Islamic State. Birmingham: UK Islamic Mission Dakwah Center, 1994.

Ali, As'ad Said. Negara Pancasila: Jalan Kemaslahatan Berbangsa. Jakarta: Pustaka LP3ES Indonesia, 2009.

Ayubi, Nazih. Political Islam: Religion and Politics in the Arab World. London and New York: Routledge, 1991.

Effendy, Bahtiar. Islam Dan Negara: Transformasi Gagasan Dan Praktik Politik Islam Di Indonesia. Jakarta: Demokrasi Project, 2011.

FPI, Forum Diskusi Santri. "NKRI Bersyariah vs Islam Nusantara," 2015. http:/ / www.suara-islam.com/read/kolom/habib-rizieq-syihab/15955/NKRIBersyariah-vs-Islam-Nusantara.

Hatta, Mohammad. Menuju Gerbang Kemerdekaan: Untuk Negeriku, Sebuah Otobiografi. Jakarta: Kompas, 2014.

IS. "Yusril: Dekrit Absah Jika Diterima Rakyat," 2013. https:/ / www.gatra.com/hukum-1/24814-yusril-dekrit-absah-jika-diterimarakyat.html.

Ma'arif, Ahmad Syafi'i. Islam as The Basis of State: A Study of the Islamic Political Ideas as Reflected in the Constituent Assembly Debates in Indonesia. Chicago, 1983.

Mardiana, Emma. "Ini Kronologi Kasus Dugaan Penodaan Pancasila Oleh Habib Rizieq," 2017. https://news.detik.com/berita/d-3409531/ini-kronologi-kasusdugaan-penodaan-pancasila-oleh-habib-rizieq.

Nurdin, Ahmad Ali. "Kaji Ulang Konsep Hubungan Islam Dan Demokrasi." Review Politik 6, no. 1 (2016).

Rahman, Fazlur. Islam. Chicago: Winston, 1966.

Shihab, al-Habib Muhammad Rizieq bin Husain. "Pengaruh Pancasila Terhadap Penerapan Syariah Islam Di Indonesia." Universiti Malaya, 2012.

Vol., John L. Esposito dan John O. Islam and Democracy. New York: Oxford University Press, 1996.

\section{Media Online}

FPI, Forum Diskusi Santri. "NKRI Bersyariah vs Islam Nusantara," 2015. http:/ / www.suara-islam.com/read/kolom/habib-rizieq-syihab/15955/NKRIBersyariah-vs-Islam-Nusantara.

https://nasional.tempo.co/read/835425/rizieq-diperiksa-polisi-fpi-bentrok-denganormas-di-bandung 12 Januari 2017 (18/3/2020).

IS. "Yusril: Dekrit Absah Jika Diterima Rakyat," 2013. https:/ / www.gatra.com/hukum-1/24814-yusril-dekrit-absah-jika-diterimarakyat.html.

Mardiana, Emma. "Ini Kronologi Kasus Dugaan Penodaan Pancasila Oleh Habib Rizieq," 2017. https://news.detik.com/berita/d-3409531/ini-kronologi-kasusdugaan-penodaan-pancasila-oleh-habib-rizieq.

Rahman, M. Taufiq. "Keadilan sosial dalam pemikiran barat dan islam: Studi Komparatif atas Pemikiran John Rawls dan Sayyid Qutb." (2012). 
Hanifiya: Jurnal Studi Agama-Agama ISSN 2089-8835

Volume 2 Nomor 2 Tahun 2019

http:// digilib.uinsgd.ac.id/13066/1/KEADILAN\%20SOSIAL\%20DALAM\%20 PEMIKIRAN\%20BARAT\%20DAN\%20ISLAM.pdf 